\title{
Preface
}

My first acquaintance with Hyderabad city was not particularly auspicious. I spent my senior year at the University of Wisconsin, Madison, in India, as a "casual student" in Miranda House, a women's college at the University of Delhi. That was in 1961-1962, and after the Indian school year ended in April, I and the other two women students on the Wisconsin program set off for a month of travel in India before heading home. We took the train from Delhi to Madras, and it stopped midway in Hyderabad, on the high Deccan plateau. We got off for a night's sleep and there at the railway station was Nampally Serai, a Mughal-style inn for travelers evoking the old princely state of the Nizams (rulers) of Hyderabad. We booked a room for three rupees four annas (less than a dollar), and being young and thrifty, we refused to spend an extra eight annas for a fan. Little did we know how hot the night would be! Even pulling our beds out into the courtyard did not save us from the smothering, punishing heat. We were glad to get on the train to Madras the next morning.

Despite this unpromising introduction to the place, I returned five years later as a graduate student in history, doing my dissertation research on a particular caste associated with the Nizam of Hyderabad's provincial Mughal administration. The Kayasths of Hyderabad, high caste Hindus from North India and Rajasthan, worked at all levels of that administration, and, like the Kayasths, who were famous for their proficiency in the Persian and Urdu languages, I learned Persian and Urdu as I learned their history and that of Hyderabad State. My husband, also a history graduate student, had learned the Telugu language of coastal Andhra for his study of social reform movements in adjacent, formerly British, India. We liked living in Hyderabad city and made many friends there.

I have many, many people to thank, as the present study draws on over forty years of contact with the city and its residents. I start with other historians of Hyderabad, people from whom I have learned much in discussions and reading over the years. Drs. H. K. Sherwani, Sarojini Regani, 
Muhammad Khalidi, Vasant Bawa, and Ziauddin Ahmed Shakeb were my earliest teachers, along with scholars among the Kayasths, particularly Roy Mahboob Narayan, Professor Mahender Raj Suxena, Gurucharan Das Saxena, Dharminder Pershad Srivastava, Kunj Behari Lal, and Hakim Vicerai. Other historians with whom I became acquainted, professional and amateur alike, include Rajendra Prasad, Narendra Luther, Rahimuddin Kemal, Asha Dua, and Bilkiz Alladin. S. A. Saleem selected and translated many articles from the Urdu newspaper Siyasat for me, and Digamber Rao also helped with translations. Dr. M. A. Muttalib helped me formulate, administer, and analyze a questionnaire at one point. I thank also the Hyderabadis who gave me Urdu and English articles and poems that they had written or found meaningful, people too numerous to list here.

Hyderabadis and others read drafts of chapters in which they were particularly expert or interested, although I am, of course, responsible for all errors of fact or interpretation. I thank the following for discussions and corrections: Dr. Omar Khalidi, Dr. Theodore Wright Jr., M. Farooq Ali Osmani, Moazzam Sheikh, Aziz Ahmed, Aziz and Habiba Razvi, Junaid Razvi, Prince Muffakham Jah, Jimmy Adams, Amina Ahmed, Mohamed Waseem, Christopher Robins, Dr. Riaz Hassan, Dr. Geoffrey Oddie, Dr. Ghaffar Mughal, Syed Zaidi, Dr. Samuel McCulloch, Dr. Raja Jayaraman, Dr. Supriya Singh, Kamala Rajah, Bruce Cox, Dennis Fallon, Betty Young, Emile Cox, Kerry Edwards, Ernest Adams, Dick Schoeffer, Joyce Corfield, Dr. Kenneth McPherson, Allaine Cerwonka, Madeline Coopsammy, Dr. Syed Ali, Dr. Syed Sirajuddin, Dr.Pnina Werbner, Drs. William and Helen Mulder, and Aziz Masood.

Lalitha and Chandrakant Gir hosted me several times in Hyderabad as I did research. I owe them special thanks for their generous assistance. Others who helped with hospitality and arrangements include Salim Beg in Lahore, Aziz Ahmed in London, Mirza Shamsher Ali Beg and Parveen and Shahid Ali Mirza in Kuwait, Anees and Maqsood Ali and Sharafat and Sultana Walajahi in Dubai, Zehra and Desh Bandhu in Toronto, and, in Australia, Geoffrey and Nola Oddie, Raja and Mythili Jayaraman, Supriya Singh, Rashmi and Judith Desai, Barney and Heather Devlin, Peter Reeves, and Kenneth McPherson.

Sources for multisite research projects are hard to find, and I am grateful to the Committee on American Overseas Research Centers, the Fulbright Foundation, the University of California, Irvine, and the Nizam's Charitable Trust for funding parts of the research. I thank also the Pemberley International Scholarly Centre of Sri Lanka for my brief stay as a resident scholar there. Special thanks to Narendra Luther, Shehbaz Safrani, Chris- 
topher Butt, Dilip Gir, and Syeda Khundkar for the photographs they supplied.

My editor at Stanford University Press, Kate Wahl, was extremely efficient and supportive throughout, and the comments of the outside readers of the manuscript proved insightful and useful. Kenneth Fox, computer consultant extraordinaire, provided indispensable help as I struggled to produce the book. Finally, I thank my children, Samuel Leonard and Sarah Olson, both of whom recently returned to Hyderabad as adults. Sam brought his spouse, Kimberly Wong, and Sarah her child, Evan Weiss, and all of them now share my affection for the city. Sarah's final incisive reading of the manuscript was absolutely invaluable.

\section{TRANSLITERATION AND TRANSLATION PRACTICES}

For Urdu, Persian, and Arabic words, I have generally followed John T. Platts, A Dictionary of Urdu, Classical Hindi, and English (London: Oxford University Press, I960) but have chosen not to use diacritical marks. Those who know the words will not miss them and others will not care. Words are defined the first time they are used and there is a glossary. To save space in a long manuscript, I have translated Urdu article titles into English in the bibliography rather than give the Urdu original followed by an English translation. 

Locating Home 
